\title{
The Viewpoints of the Teacher Candidates about the Terms of Sufficiency of Education Programme and Education Environment
}

\author{
İhsan Nuri Demirel \\ Department of Educational Sciences, Educational Management, Faculty of Education, Ağrı İbrahim Çeçen University, Turkey
}

Copyright $\bigcirc 2018$ by authors, all rights reserved. Authors agree that this article remains permanently open access under the terms of the Creative Commons Attribution License 4.0 International License

\begin{abstract}
This study is devoted to the analysis of the attitude of the teacher candidates who are having education in Ağrı Ibrahim Çeçen University, Education Faculty, Department of Elementary Turkish Education about these facts below that are accepted as the terms for the sufficiency of education programme. A-) The terms about the sufficiency of education programme: The most of the lessons in the faculty are theoretical and they are just reinforcement to main courses; there is a subject contentful in education programme of faculty; and the programme can be flexible according to the environment of educational institution and it is so extensive as to keep the students at school for long period. B-) The terms about the sufficiency of education environment: The instructors are successful at preparing the environment that makes it possible for them to learn better and they do a good job at dealing with the problems of the classroom environment and having student a healthy communication with them and also being careful about not forcing them to much about the lessons. A questionnaire is conducted to the teacher candidates in order to measure their attitude about A-) the terms about the sufficiency of education programme B-) the terms about the sufficiency of education environment. There are 121 students candidates in total that are Elementary Turkish Education Department of Ağrı İbrahim Çeçen University in the research sample. According to research finding, the teacher candidates gave different answers to the articles of the questionnaire about A-) the terms about the sufficiency of education programme and B-) the terms about the sufficiency of education environment. The findings have showed that the candidates gave different answers to a very reliable scale factor, Cronbach's Alpha value $(\alpha=0.91)$ as the mentioned by Field [5].
\end{abstract}

Keywords the Terms about the Sufficiency of Education Programme, the Terms about the Sufficiency of Education Environment

\section{Introduction}

Oktar and Bulduk have explained the importance of teacher training in [11] that focused on the following viewpoints. Educational institutions are establishments that cannot be neglected in raising the individuals the community needs. Teachers are the most basic element of these institutions. Therefore, it is necessary for teachers to be educated in the best way in both pre-service and in-service training. The negativities in teacher behaviors are the main reason of students' failure. According to Baştürk [12], teacher has an important role in the formation of subjects that society needs. Therefore, teacher training programs should be continuously reviewed and improved to have well-trained teachers.

In [13], Aslan has emphasized the relationship between the education programme of teacher training and the expectation and potentials of society. In the developing and changing world, to have well-trained teachers, every country tries to question and continuously update its education systems and teacher training policies. Teacher training is the basic element and determinant of the human education system in general terms. In the development of teacher training policies, socio-economic, socio-cultural and political developments have an important effect. In [14], according to Eşme, the basic approaches to be taken as a basis for teacher education must be determined as well as the developments in the world, taking into account the needs and potentials of the Turkish society.

It has been mentioned in Tuan et al. [6] that it is important to make students acquire cognitive properties as well as affective properties in today's educational system. It has been reported in studies of Duit and Treagust [2], Tuan et al. [6], Dede and Yaman [8] that affective field skills are an important factor in making students become successful.

Therefore, there are increasing changes in educational systems together with changes in technology, economy, and social life, impacted by globalization. As Orhan-Karsak [9] and Sahlberg [10] discussed, policies 
and educational strategies bring forward educational reforms that create new realities by establishing structures that allow for evaluations, classifications, and comparisons of national and regional educational systems.

If the issue is evaluated with the article that "most of the subjects at the faculty are theoretical", it can be said that theoretical information is an important part of the education. The study without a theoretical content will be an irregular kind of study. So, theoretical background is a must in education. But doing the education activities with just theoretical structure is not true; of course. The practical structure is also important in the activities of the educational administration. The fact that most of the subjects at the faculty are theoretical is not a problem. But the thing is that it must be done with the practical structure. Theoretical and practice must be used together. The convenience between these concepts can provide the rationality of inspection at the education educational administration.

In the study of Bursalığlu [3], according to the idea that "most of the lessons are reinforcement for the major area courses" one can understand how much the major area courses are important. There also some other subjects that are as important as the major area courses in the faculty of education. These subjects are both in the area of professional teaching knowledge and liberal education. Professional teaching knowledge subjects and liberal education reinforce the major area courses. And this is extremely important. The teacher candidates should keep in mind the fact that major area courses, professional teaching knowledge and liberal education are the subjects that constitute the block building of the education in the faculty of education. And the structure that will make it possible for the candidates to benefit well from these three categories is educational administration organization.

According to the idea that "there is subject contentful in the education programme of the faculty" offering the teacher candidate a very rich content is extremely important. However, presenting and expanding the master schedules in accordance with their flexibility feature is also critical. The subject contentful that will be presenting to the candidates in the education programmes will not only help them deal with the problems of daily life, but also it will make them ready for the job. So as a result of this situation, education administration organization should be planned in real terms with the educational economical sources.

According to the study of Adem [1] that "the education programme of the faculty can be flexible according to the conditions of educational institution", the programmes of the faculty of education shouldn't be designed according to the features of the residential areas that have just one kind of life style. The programmes of the faculty of education should have a feature of being flexible in accordance with each residential area and environment that candidates can provide service.

According to the idea that "the education programme of the faculty is so rich as to keep the students at the school" the programme of the faculty of education should be in a way that makes it possible for the students from different socio-economical and cultural backgrounds to reach the same knowledge level. Instead of keeping them in a low level socio-economical and cultural environment, making the candidates from different socio-economical and cultural environment stay at the school for long period and giving them chance to improve themselves in accordance with the rich program of the school, is crucial as the education administration organization should be fair.

According to the paper of Taymaz [7] that "The instructors are successful in preparing the suitable environments for learning opportunity" we can say that the instructors, inevitably, provide some opportunities for the candidates in educational administration organization. While providing opportunities for the candidates, the instructors should be aware of the fact that providing opportunities alone wouldn't be enough, but they also need to provide some other facilities. The instructors should keep in mind that they should also provide some healthy environments for them. For all these things, they need to have a good Educational Administration Organization.

According to the idea that "the instructors are successful in dealing with the problems that may appear at the classroom environments" we can say that developing solutions to prevent the problems to appear is as important as dealing with the problems. The instructors and the Educational Administration Organizations together, should design some rehabilitation studies for the candidates that have compliance problems. In an education process that both the instructors and Educational Administration Organizations constitute together, not many problems may appear in classroom environment.

According to the idea that "the instructors are successful in making students attend the lessons" we can say that joining the activities during the education process is so crucial. At the Educational Administration Organizations, joining the decision process of the activities is as important as joining the activities themselves. The instructors shouldn't behave timid at making the student join the lessons. The instructors shouldn't fear from the students' joining to the lesson. The instructors shouldn't think that their authority will be hurt when the students join to lesson too much. Because being active in the lesson is not the same thing with the using authority. So the instructors shouldn't refrain from the success of pushing the students to join to the lesson.

In the recent book of Demirel [4], "the instructors are successful at creating a great environment for students to have a healthy communication with them" we can say that it would be a kind of personal responsibility for the instructors to provide suitable environment. And creating this environment for a healthy communication is also a valuable result. Practicing the communication, which is making the meanings, concepts mutual between two or 
more people, is quite helpful for Educational Administration Organizations, especially for improving the teacher candidates.

According to the idea that "the instructors are in struggle for not loading too much of the lessons to students" we can say that the responsibility of the education belongs proximately to the teacher, so they don't need to be in a special struggle. At the Educational Administration Organizations, if the instructors have a competent personality, and the education directors have all qualities of a director, naturally the instructors begin to take the responsibility of lesson. This behavior may appear naturally in every single lesson.

This study aimed to discuss the qualities necessary and sufficiency in educational environments and educational programme, as well as, to raise awareness on the subject.

\section{Method}

In this study, the contents of the questionnaire forms that are used to collect information about the views of the teacher candidates of Elementary Turkish Education Department of Education Faculty of Ağrı İbrahim Çeçen University about A-) the terms about the sufficiency of education programme and $\mathrm{B}-$-) the terms about the sufficiency of education environment, are designed as proper to the aim of research. This questionnaire forms, are made suitable according to data processing method with help of the views of authors. The trial forms prepared for this purpose are applied to two groups at Department of Education Faculty of Ağrı İbrahim Çeçen University. According to the data of trial test, it is witnessed that some questions didn't work out. In order to ensure the validity and reliability of the test, which are crucial elements of assessment and evaluation instrument, the questions that didn't work out are taken out and the last version of the test is done. The information at the questionnaire forms that are taken by the teacher candidates studying at Department of Education Faculty of Ağrı İbrahim Çeçen University is analyzed. Before it is finalized, the information at the forms is developed as particular tables by the researcher. These tables play an important role in finalizing the test.

The teacher candidates of Elementary Turkish Education Department of Education Faculty of Ağrı İbrahim Çeçen University are asked to express accuracy rating of their views about A-) the terms about the sufficiency of education programme and $\mathrm{B}-$-) the terms about the sufficiency of education environment, as "absolutely disagree", "disagree", "neutral", "agree" absolutely agree". And the rating of these are "1, 2, 3, 4 and 5". According to this way, the grade of accuracy is expressed as percentages.

\section{Population and Sample}

The population of the research consists of the candidates that are studying at Elementary Turkish Education Department of Education Faculty of Ağrı İbrahim Çeçen
University. The institution lists of theacher candidates Elementary Turkish Education Department of Education Faculty of Ağrı İbrahim Çeçen University are taken as a basis. It is possible to say that sample is similar to population, as the basis is accepted as reaching most of the candidates. A group of 121 people from the candidates from Elementary Turkish Education Department of Education Faculty of Ağrı İbrahim Çeçen University is examined. Sample is done with the purpose of taking teacher candidates and this purpose is done to a large extent. Moreover, the fractions of the numbers are ignored when the percentages of the research is calculated. If there is a deficiency about reaching $100 \%$ rate, or about the total of "I agree" and "absolutely agree options, which are preferred options, the reason of this is not expressing the fractions of the numbers.

\section{Data Collection}

Each single person of the group of 121 candidates did the questionnaire. There is no invalid form. Nearly whole of the candidates from Elementary Turkish Education Department of Education Faculty of Ağrı İbrahim Çeçen University is applied the questionnaire. They were asked to fill the forms according to the rules

\section{Problem}

The level of the views of the teacher candidates studying at Department of Education Faculty of Ağrl İbrahim Çeçen University about A-) the terms about the sufficiency of education programme and B-) the terms about the sufficiency of education environment

\section{Sub Problem}

What is the level the views of the teacher candidates studying at Department of Education Faculty of Ağr1 İbrahim Çeçen University about A-) the terms about the sufficiency of education programme and B-) the terms about the sufficiency of education environment?

\section{Hypothesis}

The level the views of the teacher candidates studying at Department of Education Faculty of Ağrı İbrahim Çeçen University about A-) the terms about the sufficiency of education programme and B-) the terms about the sufficiency of education environment, is up to the mark.

\section{Premises}

1. Preliminary test being done for improving the questionnaire is satisfactory.

2. Authors view being taken for improving the questionnaire is satisfactory.

3. The views of the teacher candidates studying at Department of Education Faculty of Ağrı İbrahim Çeçen University reflect the truth.

4. The selected research method is suitable to the aim. 
5. Representation of the sample is at the desired size.

6. The questionnaire and the questions of the questionnaire are valid and reliable.

7. The datum is confirmed as valid and reliable.

\section{Limitations}

1. This research is limited to the views of the teacher candidates studying at Department of Education Faculty of Ağrı İbrahim Çeçen University.

2. This research is limited to resources and the questionnaires that can be reached as collecting data means

\section{Findings}

In this section, the views of the teacher candidates studying at Department of Education Faculty of Ağr1 İbrahim Çeçen University about A-) the terms about the sufficiency of education programme and B-) the terms about the sufficiency of education environment are listed by means of the tables. The teacher candidates of Turkish Education Department of Education Faculty of Ağr1 İbrahim Çeçen University are asked to express accuracy rating of their views about $\mathrm{A}-$ ) the terms about the sufficiency of education programme and B-) the terms about the sufficiency of education environment, as "absolutely disagree", "disagree", "neutral", "agree" absolutely agree". And the rating of these are "1, 2, 3, 4 and 5 " as stated above.

The views about A-) the terms about the sufficiency of education programme and B-) the terms about the sufficiency of education environment are listed by means of the tables. "Agree" absolutely agree" options are accepted as desired options.

\section{A-) The Terms About the Sufficiency of Education Programme:}

Table 1. The most of the lessons in the research are theoretical.

\begin{tabular}{|c|c|c|c|c|c|}
\hline & & Frequency & Percent & $\begin{array}{c}\text { Valid } \\
\text { Percent }\end{array}$ & $\begin{array}{c}\text { Cumulative } \\
\text { Percent }\end{array}$ \\
\hline \multirow{5}{*}{ Valid } & $\begin{array}{l}\text { I don't } \\
\text { agree }\end{array}$ & 27 & 22,3 & 22,3 & 22,3 \\
\hline & Neutral & 5 & 4,1 & 4,1 & 26,4 \\
\hline & I agree & 54 & 44,6 & 44,6 & 71,1 \\
\hline & $\begin{array}{c}\text { I } \\
\text { completely } \\
\text { agree } \\
\end{array}$ & 35 & 28,9 & 28,9 & 100,0 \\
\hline & Total & 121 & 100,0 & 100,0 & \\
\hline
\end{tabular}

As it is seen in the table, there is no "I don't agree ever", and there are 27 candidates saying "I don't agree", 5 candidates "neutral", 54 candidates "I agree" and 35 candidates "I completely agree".
Table 2. Most of the lessons at the faculty are the reinforce lessons

\begin{tabular}{|c|c|c|c|c|c|}
\hline & & Frequency & Percent & $\begin{array}{l}\text { Valid } \\
\text { Percent }\end{array}$ & $\begin{array}{c}\text { Cumulative } \\
\text { Percent }\end{array}$ \\
\hline \multirow{6}{*}{ Valid } & $\begin{array}{c}\text { I don't } \\
\text { agree ever }\end{array}$ & 8 & 6,6 & 6,6 & 6,6 \\
\hline & $\begin{array}{l}\text { I don't } \\
\text { agree }\end{array}$ & 41 & 33,9 & 33,9 & 40,5 \\
\hline & Neutral & 16 & 13,2 & 13,2 & 53,7 \\
\hline & I agree & 55 & 45,5 & 45,5 & 99,2 \\
\hline & $\begin{array}{c}\text { I } \\
\text { completely } \\
\text { agree }\end{array}$ & 1 &, 8 & ,8 & 100,0 \\
\hline & Total & 121 & 100,0 & 100,0 & \\
\hline
\end{tabular}

As it is seen in the table there is 8 candidates "I don't agree ever", and there are 41 candidates said "I don't agree", 16 candidates "neutral", 55 candidates "I agree" and 1 candidate "I completely agree". The expectations of the teacher candidates of the 53\% (56 candidates) are realized as desired.

Table 3. There is subject contentful in the education programme

\begin{tabular}{|c|c|c|c|c|c|}
\hline & & Frequency & Percent & $\begin{array}{c}\text { Valid } \\
\text { Percent }\end{array}$ & $\begin{array}{c}\text { Cumulative } \\
\text { Percent }\end{array}$ \\
\hline \multirow{6}{*}{ Valid } & $\begin{array}{c}\text { I don't } \\
\text { agree ever }\end{array}$ & 10 & 8,3 & 8,3 & 8,3 \\
\hline & $\begin{array}{l}\text { I don't } \\
\text { agree }\end{array}$ & 45 & 37,2 & 37,2 & 45,5 \\
\hline & Neutral & 23 & 19,0 & 19,0 & 64,5 \\
\hline & I agree & 37 & 30,6 & 30,6 & 95,0 \\
\hline & $\begin{array}{c}\text { I } \\
\text { completely } \\
\text { agree }\end{array}$ & 6 & 5,0 & 5,0 & 100,0 \\
\hline & Total & 121 & 100,0 & 100,0 & \\
\hline
\end{tabular}

As it is seen in the table there is 10 candidates "I don't agree ever", and there are 45 candidates said "I don't agree", 23 candidates "neutral", 37 candidates "I agree" and 6 candidates "I completely agree". The expectations of the teacher candidates of the $35 \%$ (43 candidates) are realized as desired.

Table 4. The education program of the faculty can be flexible according to the conditions of the education institution

\begin{tabular}{|c|c|c|c|c|c|}
\hline & & Frequency & Percent & $\begin{array}{c}\text { Valid } \\
\text { Percent }\end{array}$ & $\begin{array}{c}\text { Cumulative } \\
\text { Percent }\end{array}$ \\
\hline \multirow{6}{*}{ Valid } & $\begin{array}{c}\text { I don't } \\
\text { agree ever }\end{array}$ & 11 & 9,1 & 9,1 & 9,1 \\
\hline & $\begin{array}{l}\text { I don’t } \\
\text { agree }\end{array}$ & 27 & 22,3 & 22,3 & 31,4 \\
\hline & Neutral & 26 & 21,5 & 21,5 & 52,9 \\
\hline & I agree & 51 & 42,1 & 42,1 & 95,0 \\
\hline & $\begin{array}{c}\text { I } \\
\text { completely } \\
\text { agree }\end{array}$ & 6 & 5,0 & 5,0 & 100,0 \\
\hline & Total & 121 & 100,0 & 100,0 & \\
\hline
\end{tabular}

As it is seen in the table, there are 11 candidates "I don't agree ever", and there are 27 candidates said "I don't agree", 26 candidates "neutral", 51 candidates "I agree" and 6 candidates "I completely agree". The expectations of the teacher candidates of the $47 \%$ (57 candidates) are realized as desired. 
Table 5. The program of the faculty is so rich as to keep the students at school

\begin{tabular}{|c|c|c|c|c|c|}
\hline & & Frequency & Percent & $\begin{array}{c}\text { Valid } \\
\text { Percent }\end{array}$ & $\begin{array}{c}\text { Cumulative } \\
\text { Percent }\end{array}$ \\
\hline \multirow{6}{*}{ Valid } & $\begin{array}{c}\text { I don't } \\
\text { agree ever }\end{array}$ & 27 & 22,3 & 22,3 & 22,3 \\
\hline & $\begin{array}{c}\text { I don't } \\
\text { agree }\end{array}$ & 56 & 46,3 & 46,3 & 68,6 \\
\hline & Neutral & 24 & 19,8 & 19,8 & 88,4 \\
\hline & I agree & 12 & 9,9 & 9,9 & 98,3 \\
\hline & $\begin{array}{c}\text { I } \\
\text { completely } \\
\text { agree }\end{array}$ & 2 & 1,7 & 1,7 & 100,0 \\
\hline & Total & 121 & 100,0 & 100,0 & \\
\hline
\end{tabular}

As it is seen in the table, there are 27 candidates "I don't agree ever", and there are 56 candidates said "I don't agree", 24 candidates "neutral", 12 candidates "I agree" and 2 candidates "I completely agree". The expectations of the teacher candidates of the $10 \%$ (14 candidates) are realized as desired.

\section{B-) The Terms about the Sufficiency of Education Environment:}

Table 6. The instructors are successful in preparing the suitable environments for learning opportunity.

\begin{tabular}{|c|c|c|c|c|c|}
\hline & & Frequency & Percent & $\begin{array}{c}\text { Valid } \\
\text { Percent }\end{array}$ & $\begin{array}{c}\text { Cumulative } \\
\text { Percent }\end{array}$ \\
\hline \multirow{6}{*}{ Valid } & $\begin{array}{c}\text { I don't } \\
\text { agree ever }\end{array}$ & 14 & 11,6 & 11,6 & 11,6 \\
\hline & $\begin{array}{c}\text { I don't } \\
\text { agree }\end{array}$ & 48 & 39,7 & 39,7 & 51,2 \\
\hline & Neutral & 34 & 28,1 & 28,1 & 79,3 \\
\hline & I agree & 21 & 17,4 & 17,4 & 96,7 \\
\hline & $\begin{array}{c}\text { I } \\
\text { completely } \\
\text { agree }\end{array}$ & 4 & 3,3 & 3,3 & 100,0 \\
\hline & Total & 121 & 100,0 & 100,0 & \\
\hline
\end{tabular}

As it is seen in the table, there are 14 candidates "I don't agree ever", and there are 48 candidates said "I don't agree", 34 candidates "neutral", 21 candidates "I agree" and 4 candidates "I completely agree". The expectations of the teacher candidates of the $20 \%$ (25 candidates) are realized as desired.

Table 7. The instructors are successful in dealing with the problems that may appear at the classroom environments

\begin{tabular}{|c|c|c|c|c|c|}
\hline & & Frequency & Percent & $\begin{array}{c}\text { Valid } \\
\text { Percent }\end{array}$ & $\begin{array}{c}\text { Cumulative } \\
\text { Percent }\end{array}$ \\
\hline \multirow{6}{*}{ Valid } & $\begin{array}{c}\text { I don't } \\
\text { agree ever }\end{array}$ & 7 & 5,8 & 5,8 & 5,8 \\
\hline & $\begin{array}{l}\text { I don't } \\
\text { agree }\end{array}$ & 27 & 22,3 & 22,3 & 28,1 \\
\hline & Neutral & 29 & 24,0 & 24,0 & 52,1 \\
\hline & I agree & 50 & 41,3 & 41,3 & 93,4 \\
\hline & $\begin{array}{c}\text { I } \\
\text { completely } \\
\text { agree }\end{array}$ & 8 & 6,6 & 6,6 & 100,0 \\
\hline & Total & 121 & 100,0 & 100,0 & \\
\hline
\end{tabular}

As it is seen in the table, there are 7 candidates "I don't agree ever", and there are 27 candidates said "I don't agree", 29 candidates "neutral", 50 candidates "I agree" and 8 candidates "I completely agree". The expectations of the teacher candidates of the $47 \%$ (58 candidates) are realized as desired.

Table 8. The instructors are successful in making students attend the lessons.

\begin{tabular}{|c|c|c|c|c|c|}
\hline & & Frequency & Percent & $\begin{array}{l}\text { Valid } \\
\text { Percent }\end{array}$ & $\begin{array}{c}\text { Cumulative } \\
\text { Percent }\end{array}$ \\
\hline \multirow{6}{*}{ Valid } & $\begin{array}{c}\text { I don't } \\
\text { agree ever }\end{array}$ & 11 & 9,1 & 9,1 & 9,1 \\
\hline & $\begin{array}{l}\text { I don't } \\
\text { agree }\end{array}$ & 44 & 36,4 & 36,4 & 45,5 \\
\hline & Neutral & 30 & 24,8 & 24,8 & 70,2 \\
\hline & I agree & 34 & 28,1 & 28,1 & 98,3 \\
\hline & $\begin{array}{c}\text { I } \\
\text { completely } \\
\text { agree }\end{array}$ & 2 & 1,7 & 1,7 & 100,0 \\
\hline & Total & 121 & 100,0 & 100,0 & \\
\hline
\end{tabular}

As it is seen in the table, there are 11 candidates "I don't agree ever", and there are 44 candidates said "I don't agree", 30 candidates "neutral", 34 candidates "I agree" and 2 candidates "I completely agree". The expectations of the teacher candidates of the $29 \%$ (36 candidates) are realized as desired.

Table 9. The instructors are successful in creating a great environment for students to have a healthy communication with them" are as desired.

\begin{tabular}{|c|c|c|c|c|c|}
\hline & & Frequency & Percent & $\begin{array}{c}\text { Valid } \\
\text { Percent }\end{array}$ & $\begin{array}{c}\text { Cumulative } \\
\text { Percent }\end{array}$ \\
\hline \multirow{6}{*}{ Valid } & $\begin{array}{c}\text { I don't } \\
\text { agree ever }\end{array}$ & 18 & 14,9 & 14,9 & 14,9 \\
\hline & $\begin{array}{c}\text { I don’t } \\
\text { agree }\end{array}$ & 48 & 39,7 & 39,7 & 54,5 \\
\hline & Neutral & 26 & 21,5 & 21,5 & 76,0 \\
\hline & I agree & 26 & 21,5 & 21,5 & 97,5 \\
\hline & $\begin{array}{c}\text { I } \\
\text { completely } \\
\text { agree }\end{array}$ & 3 & 2,5 & 2,5 & 100,0 \\
\hline & Total & 121 & 100,0 & 100,0 & \\
\hline
\end{tabular}

As it is seen in the table, there are 18 candidates "I don't agree ever", and there are 48 candidates said "I don't agree", 26 candidates "neutral", 26 candidates "I agree" and 3 candidates "I completely agree". The expectations of the teacher candidates of the $24 \%$ (29 candidates) are realized as desired.

Table 10. The instructors are in struggle for not loading too much of the lessons to students are as desired

\begin{tabular}{|c|c|c|c|c|c|}
\hline & & Frequency & Percent & $\begin{array}{c}\text { Valid } \\
\text { Percent }\end{array}$ & $\begin{array}{c}\text { Cumulative } \\
\text { Percent }\end{array}$ \\
\hline \multirow{6}{*}{ Valid } & $\begin{array}{c}\text { I don't } \\
\text { agree ever }\end{array}$ & 32 & 26,4 & 26,4 & 26,4 \\
\hline & $\begin{array}{c}\text { I don't } \\
\text { agree }\end{array}$ & 54 & 44,6 & 44,6 & 71,1 \\
\hline & Neutral & 20 & 16,5 & 16,5 & 87,6 \\
\hline & I agree & 13 & 10,7 & 10,7 & 98,3 \\
\hline & $\begin{array}{c}\text { I } \\
\text { completely } \\
\text { agree }\end{array}$ & 2 & 1,7 & 1,7 & 100,0 \\
\hline & Total & 121 & 100,0 & 100,0 & \\
\hline
\end{tabular}

As it is seen in the table, there are 32 candidates "I don't agree ever", and there are 54 candidates said "I don't agree", 20 candidates "neutral", 13 candidates "I agree" 
and 2 candidates "I completely agree". The expectations of the teacher candidates of the $11 \%$ (15 candidates) are realized as desired.

\section{Results}

1. The attitudes of the $72 \%$ of the ( 89 persons) candidates towards "Most of the subjects at the faculty are theoretical." are as desired. These attitudes are important things to be taken in consideration.

2. The attitudes of the $53 \%$ of the (56 persons) candidates towards "most of the lessons are reinforcement for the major area courses" are as desired. With regards to the education system, these attitudes are important achievement with regards to the system.

3. The attitudes of the $35 \%$ of the ( 43 persons) candidates towards "there is a subject contentful in the education programme of the faculty" are as desired. As the most of the candidates' state that there isn't a subject contentful at the faculty" this must be a big problem for the education department.

4. The attitudes of the $47 \%$ of the ( 57 persons) candidates towards "the education programme of the faculty can be flexible according to the conditions of educational institution" are as desired. More than $50 \%$ of the candidates state that the conditions of the education institution are not sufficient. And this means there are some deficiencies about the subject of being flexible.

5. The attitudes of the $10 \%$ of the (14 persons) candidates towards "the education programme of the faculty is so rich as to keep the students at the school" are as desired. As the much more than $50 \%$ of the candidates state that the program isn't a rich enough to keep them at the faculty" this must be a big problem for the education department and the member of the department.

6. The attitudes of the $20 \%$ of the ( 25 persons) candidates towards "The instructors are successful in preparing the suitable environments for learning opportunity" are as desired. As much more than $50 \%$ of the candidates state that the instructors are successful in preparing the suitable environments for learning opportunity, this is an important thing to be taken in consideration by the department.

7. The attitudes of the $47 \%$ of the ( 58 persons) candidates towards "the instructors are successful in dealing with the problems that may appear at the classroom environments" are as desired. Nearly $50 \%$ of the candidates state the instructors are successful in dealing with the problems, and this an interesting result.

8. The attitudes of the $29 \%$ of the ( 36 persons) candidates towards "the instructors are successful in making students attend the lessons" are desired. As more than $50 \%$ of the candidates state that the instructors are not successful in making students attend the lessons, this is an important thing to be taken in consideration by the department.

9. The attitudes of the $24 \%$ of the ( 29 persons) candidates towards "the instructors are successful in creating a great environment for students to have a healthy communication with them" are as desired. As more than $50 \%$ of the candidates state that the instructors are not successful in creating a great environment for students to have a healthy communication with them, this must be a big problem for the education department and the member of the department.

10 . The attitudes of the $11 \%$ of the ( 15 persons) candidates towards "the instructors are in struggle for not loading too much of the lessons to students in" are as desired. More than $50 \%$ of the candidates emphasize that the instructors are not in struggle for not loading too much of the lessons to students, and this means that the instructors do the education activities by getting out burden of the course.

\section{Suggestions}

1. As the attitudes of the $72 \%$ of the ( 89 persons) candidates towards "Most of the subjects at the faculty are theoretical" are as desired, administrators must search the ways of providing the balance of theoretic-practice.

2. As the attitudes of the $53 \%$ of the (56 persons) candidates towards "most of the lessons are reinforcement for the major area courses" are as desired, it should be a warning to administers that major area courses are closely united with the general culture courses and professional teaching knowledge courses.

3. As the attitudes of the $35 \%$ of the (43 persons) candidates towards "there is a subject contentful in the education programme of the faculty" are as desired, it should be a warning to administers about the fact that there is no contentful in education program.

4. As The attitudes of the $47 \%$ of the ( 57 persons) candidates towards "the education programme of the faculty can be flexible according to the conditions of educational institution" are as desired; this should encourage administer to improve the flexibility of the program.

5. As the attitudes of the $10 \%$ of the (14 persons) candidates towards "the education programme of the faculty is so rich as to keep the students at the school" are as desired, this should encourage administers to upgrade the contentful of the education programmes.

6. As the attitudes of the $20 \%$ of the ( 25 persons) candidates towards "The instructors are successful in preparing the suitable environments for learning opportunity" are as desired, this should make the administers to make studies about the environments offering the opportunities of learning. 
7. As the attitudes of the $47 \%$ of the (58 persons) candidates towards "the instructors are successful in dealing with the problems that may appear at the classroom environments" are as desired, this is a positive thing for the education department. However, the department should take precautions before the problems arise.

8. As the attitudes of the $29 \%$ of the (36 persons) candidates towards "the instructors are successful in making students attend the lessons" are desired. This should encourage administers and instructors to create environment convenient for students' attending the lessons.

9. As the attitudes of the $24 \%$ of the ( 29 persons) candidates towards "the instructors are successful in creating a great environment for students to have a healthy communication with them" are as desired; this should make the administers to work hard about lack of communication.

10. As the attitudes of the $11 \%$ of the (15 persons) candidates towards "the instructors are successful in creating a great environment for students to have a healthy communication with them" are as desired; the department show sensibility about taking the burden course from students, which they loaded before, under the guise of student-centered education.

\section{REFERENCES}

[1] Adem, Mahmut. Educational Planning. Sevinç Press, Ankara, 1981.

[2] Duit, R. and Treagust, D. (2003). Conceptual change: A powerful framework for improving science teaching and learning. International Journal of Science Education, 25 (6), 671-688.
[3] Bursalığlu, Ziya. The new structure and Behaviour at School Management. Ankara Üniversity the Faculty of Educational Sciences Press Number: 154, Extended $7^{\text {th }}$ Press Ankara, 1987.

[4] Demirel, İhsan Nuri. Under 100 questions, The Planning of Education Management Inspection and Economy. $8^{\text {th }}$ press, Ankara, 2017

[5] Field, A. Discovering statistics using IBM SPSS statistics. sage. 2013

[6] Tuan, Chin \& Shieh (2005). The development of a questionnaire to measure students' motivation towards science learning. International Journal of Science Education, Vol 27 (6), 634-659.

[7] Taymaz, Haydar. In Service Training. A.Ü. Education Faculty Press, Ankara, 1981.

[8] Dede, Y. and Yaman, S. (2008). Fen Öğrenmeye Yönelik Motivasyon Ölçeği: Geçerlik ve Güvenirlik Çalışması. Necatibey Eğitim Fakültesi Elektronik Fen ve Matematik Eğitimi Dergisi (EFMED) 2 (1), 19-37.

[9] Orhan-Karsak, H.G. (2017). Reflections of the Changing Education System According to the Views of School Managers: Turkey Sample. Universal Journal of Educational Research 5 (8): 1308-1322.

[10] Sahlberg, P. (2006). Education reform for raising economic competitiveness. Journal of Educational Change, 7, 259-287.

[11] Oktar, İ., ve Bulduk, S. (1999). Ortaöğretim kurumlarında çalışan öğretmenlerin davranışlarının değerlendirilmesi. Milli Eğitim Dergisi, (142).

[12] Baştürk, S. (2011). Matematik öğretmen adaylarının eğitim fakültesindeki eğitim-öğretim sürecini değerlendirmeleri, Uluslararsı İnsan Bilimleri Dergisi, 8 (1).

[13] Aslan, K. (2003). Eğitim fakültelerinin yeniden yapılandırılmalarına ilişkin bir değerlendirme. Balıkesir Üniversitesi Sosyal Bilimler Enstitüsü Dergisi, 6 (9), 23-37.

[14] Eşme, İ. (1998). Bilgi toplumunda öğretmen yetiştirme. Milli Eğitim Dergisi, 138, 3-6. 